\title{
SWOT Analysis of e-Initiative in Uttarakhand
}

\author{
Kunwar Singh Vaisla \\ Department of Computer Science \& Engineering, \\ BCT Kumaon Engineering College, \\ Dwarahat - 263653, Almora (Uttarakhand), INDIA
}

\author{
Manoj Kumar Bisht \\ Department of Computer Science, \\ SSJ Campus, Kumaon University,
}

Almora (Uttarakhand), INDIA

\begin{abstract}
Uttarakhand, having completed more than 9 years as a separate state, is now poised to embark on a new era of rapid development and inclusive growth. The broad features of the administrative structure and systems, extending from the state to the district and sub-district levels, are now in place, though the problem of shortage of manpower in crucial areas remains. The Eleventh Five Year Plan gives a good opportunity to launch the State on the path of rapid and sustained growth with emphasis on rural development, education and welfare of the state. The previous plan was prepared at a time when the State was quite young. The administrative system was in the stage of infancy and adequate administrative support and expert assistance for planning were not available. The financial resource position of the State was quite precarious, when the State came into existence. Despite constraints, Uttarakhand has made rapid advancement and has posted a significant high rate of growth.
\end{abstract}

Keywords: e-Governance, Good-Governance, e-initiatives; impact analysis; SWOT Analysis.

\section{INTRODUCTION:}

\subsection{Stages in e-Initiatives}

e-Initiatives are about service delivery to the citizens using the Information and communication Technologies. The e-Initiatives go through three distinct levels of implementation. These stages in the e-Initiatives are:

Provision of static information: This stage is where a local body/government department has a portal of its own. Citizens can access information, seek procedural details about city services. However, they can't interact with any of the processes within the Local Body (LB)/department.

Capability for Transactional Services: This stage is where users can carry out transactions online.

Creating Online Communities: At this stage, LB websites provide interoperability with various organizations. Majority of current -initiatives fall under the first stage [4].

The general use problems in the e-Initiatives system are: No clarity in the setup of Civic authority, poor information availability on initiatives, lack of clarity on procedures, time consuming processes, lack of accountability of officials of the system, too many agencies and overlap of work.

\section{2 e-Initiatives challenges}

There has been tremendous success of e-Initiatives in the country. In early 1990's most of the states in India started implementing the e-Initiatives. Process SMART has been implemented in the Government of Andhra Pradesh in 1992. It focuses on Simple, Moral, Accountable, Reachable, and Transparent Principle for the successful implementation of e- strategies. Many states have successfully implemented eStrategies there after. However, there are many implementing challenges in deploying the e-Initiatives. They are:

- Infrastructure capacity

- Compatibility with other IT systems/ databases/ platforms

- Scalability of existing applications

- Information exchange mechanisms

- Geo referencing of assets

- Ability to carry out financial transactions

The Span and reach of e-Initiatives may primarily focus on the following:

- Various levels of administrative set-up from village/ block to State/Central agencies

- Non-governmental social agencies

- Connecting citizens to the above agencies

The main purpose of developing e-Initiatives is to develop an effective, rapid, accountable and self-sustaining mechanism for the betterment of social service through multi-layered system.

e-Initiatives are basically the concerns of governmental organizations which are to be utilized by the larger society for tackling major as well as day- to-day problems of ordinary citizens. The over all strategy for e-Initiatives is to develop methods to be used for the society using ICTs.

The state of Uttarakhand is engaged in this endeavor for the last about ten years. It is high time for a proper investigation and the assessment of the impact of e-Initiatives of the state.

\subsection{Objectives}

The objective of Educational qualification wise groups of the respondents does not differ in their mean IAOEIU (Impact Assessment of e-Initiative in Uttarakhand) scores.

There exists no significant difference in the mean IAOEIU scores of gender wise two groups of the students.

Age wise four groups of the respondents do not differ from one another with regard to their mean IAOEIU scores.

The present research work is to study the impact assessment of various e-Initiatives of Uttarakhand state with special focus on effectiveness and countable measures related to the implementation.

To address the objective, the following research questions have been undertaken:

- To describe and examine the e-Initiatives undertaken and initiated by the Central government.

- To describe and examine the attempts made by the State of Uttarakhand with regard to e-Initiatives. 
- To analyze and understand the perceptions of experts towards the effectiveness of e-Initiatives in Uttarakhand.

- To collect and elaborate the comments of the experts on e-Initiatives in Uttarakhand.

\subsection{Hypothesis}

The following three null hypotheses have been framed to attain the objective No. 3 of the study:

\subsection{Delimitation of the Study}

The study has been delimited as mentioned below:

- Perception towards the effectiveness of e-Initiatives deals with the 14 main e- endeavors of the state of Uttarakhand.

- A total of 148 respondents were contacted keeping in view their familiarity with the issues-concerned and their willingness to provide the responses. It means that Purposive sampling techniques was used to identify these respondents.

- Actual field survey technique has not been used to find out the effectiveness of e-Initiatives. It has been done by taking into consideration relevant groups of respondents.

\section{LITERATURE REVIEW}

\section{1 e-Initiatives Global Scenario:}

Government of Colombia Portal [5], TaniNet -An agricultural community development in Malaysia [6], Namibian Parliamentary [7], Procurement System, Chile [8], The Tiger Leap Initiative, Estonia [9], Exchange to improve health care services to the rural poor, State of the Environment Report, South Africa[10], Election Register, Palestine [11], Citizen Service Centers, Bahia Province, Brazil [12].

\subsection{National Scenario}

The government of India recognizes that some good eInitiatives like e-Governances, provides an excellent opportunity for improving governance. It is a trigger for introducing various administrative reforms. This could not only go a long way in improving the quality of life of various sections of society, but could actually provide them more equitable access to economic opportunities ever before. In this context, the Government of India views e-Initiative as a strategic tool for transforming Governance and improving the quality of services provided by the government to its people [13].

India's experience in e-Governance/ ICT initiatives has demonstrated significant success in improving accessibility, cutting down costs, reducing corruption, extending help and increased access to un-served groups. In this phase of experimentation, many e-Initiatives have reached millions of people belonging to various sections of society. Improved access to information and services has provided economic and social development opportunities, facilitated participation and communication in policy and decision-making processes and empowerment of the weaker groups. This has led to fostering a sense of ownership and building of social capital, which in turn, constitute a basis for local revitalization. The Government of India, in various forums, has indicated its commitment to provide efficient and transparent government to all strata of society.

e-Governance is now mainly seen as a key element of the country's governance and administrative reform agenda. India has undertaken massive e-Initiatives to introduce e-Governance at the national, state and local levels. In terms of the total number of government websites, although the advanced industrial countries top the list, India is ranked seventh in the global list [14]. Similar to the previously mentioned common rationales, the top policy-makers in India tend to justify the adoption and expansion of e-Governance on the grounds that it costs less, reduces waste, promotes transparency, eliminates corruption, generates possibilities to resolve rural poverty and inequality, and guarantees a better future for citizens [15]. In short, the government tends to portray e-Governance as the panacea for all ranges of problems confronting India, but there are critics who, in general, suggest that the whole enterprise of ICT may have created a new class of 'untouchables' living in 'information poverty', compromised equal access to government services and eroded accountability and individual privacy [16].

\section{3 e-Initiatives experiences in India}

Recognizing that e-Governance shall be a major part of eInitiatives and shall play an increasingly important role in modern Governance, various agencies of the Government and civil society organizations have taken a large number of eInitiatives across the country. Indicated below are some of the key e-Initiatives taken in the country across some of the important citizen/business related departments.

- Customs and Excise (Government of India)

- Indian Railways (Government of India)

- Postal Department (Government of India)

- $\quad$ Passport / Visa (Government of India)

- AP Online (State Government of Andhra Pradesh)

- Bhoomi

- $\quad$ CARD - Registration Project (State Government of Andhra Pradesh)

- Gyandoot: Intranet in Tribal District of Dhar (State Government of Madhya Pradesh)

- Lokmitra (State Government of Himanchal Pradesh)

- e-Mitra - Integrated Citizen Services Center (State Government of Rajasthan)

The above cases of e-Initiatives are only illustrative. Many of the State Governments have successfully implemented several such e-Initiatives. This has positively impacted the quality of life of citizens. Hence e-Governance as a major e-Initiative affords an excellent opportunity for India to radically improve the quality of governance and thereby:

Allows two-way communication between government and citizens not only for service delivery but also to receive opinions of citizens on policies and government performance. 
Provides greater access to excluded groups, who have few opportunities to interact with government and benefit from its services and schemes.

Includes all sections of the society in the mainstream of development.

Enabling rural and traditionally marginalized segments of the population to gain fast and convenient access to services in their own neighborhoods.

\subsection{The National e-Governance Plan (NeGP)}

Taking note of the potential of e-Governance to improve the quality of life of the vast population of the country, the Government of India has formulated a national programme the National e-Governance Plan (NeGP). This plan attempts to cover all the important areas relating to e-Governance - Policy, Infrastructure, Finances, Project Management, Government Process Reengineering, Capacity Building, Training, Assessment and Awareness etc. across the Central and State Governments.

NeGP is a comprehensive "programme" of the Government of India and is designed to leverage capabilities and opportunities presented by ICT to promote good governance across the country. One of the learning that is at the core of the NeGP is the emphasis on implementation of such projects with clear timelines and responsibility allocations - in a "Mission Mode". The Plan initially extends over a 4-year period at an estimated cost of over USD 3 billion. NeGP is aimed at introducing eGovernance systematically through 25 Mission Mode projects, which would touch the lives of more than 1 billion people [17]. The vision of NeGP is to make all Government services accessible to the common man in his locality through common service delivery outlets. The implementation strategy envisages clear definition of service goals and metrics for each project and structured stakeholder consultations with all stakeholders including citizens and civil society organizations before the service goals of each project are firmed up. Even at the stage of formulation of the NeGP, its vision and proposed strategy, consultations were held with various stakeholders including state governments, ministries/ departments, IT industry representatives and civil society organizations. The focus of the plan includes the following sectors/projects:

- Agriculture

- Municipalities

- Gram Panchayats (elected village administration)

- Common Service Centers (CSCs)

\subsection{Centrally initiated e-Governance projects}

The Government of India initiatives may e-Governance project under the e-Governance (G2C) Category. There project are

- Land Records Computerization at Tahsil Level

- Land Records Citizen Centric Website

- Transport Office Computerization

- MIS Development for Jal Sansthan (Pey Jal) Department, Uttarakhand
- AGMARKNET

- $\quad$ Right To Information (RTI) Website

- CONFONET (Computerization of State/District Consumer Forums)

- Multipurpose National Id-Card (MNIC) Project

- MIS for National Rural Employment Guarantee Assurance (NREGA) Programme

- Unique Id-Project for Residents

- Common Integrated Police Application (CIPA)

The present investigation primarily aims to investigate the impact assessment of the Uttarakhand state. It endeavors to evaluate impact of various e-Initiatives taken by the Government.

The findings of this study are expected to be of paramount significance to a variety of groups such as:

- Government officials who are responsible for the eInitiatives implementation in Uttarakhand. The study as a whole is directed to meet the needs of this group by finding obstacles to adoption, proposing solutions and illustrating critical success factors.

- Officials and users from the public and private sector responsible for e-Initiatives like e-Governance and ecommerce.

- Scholars researching e-Governance.

The key issue within the context of e-Initiatives is the delivery of e-Governance applications its citizen, which is the process of making available the use of e-Governance services for all types of users, in an efficient and convenient manner. The government can provide value by providing service delivery which consists of the location timing and manner by which it is distributed [18]. At the start level, e-governance features include being open for State citizen and business users 24 hours a day, greater accessibility, lower costs and not having to visit government offices; it also aims to provide government information. Thus, to a large extent, e-Initiatives refer to the initiatives in e-Governance [19].

In India e-Governance began with National Informatics Center's (NICs) efforts to connect district headquarters through computers. The approach over the years has grown out of same idea. The concept has been dominated by connectivity, networking, technological up-gradation, selective delivery systems for information's and services, and an array of software solutions.

The central government has created full-fledged ministry called Ministry of Information and communication Technologies (MICT) [20]. The ministry is responsible for monitoring the development and use of IT in various facets of working and initiate steps to remove the bottlenecks, if any. To give further impetus to e-Governance, a Center for Electronic Governance has been established in the MICT to coordinate the initiatives in e-Governance.

According to National e-Governance Action Plan (2003-2007), government has approved a number of Mission Mode projects 
for implementation under the central government like income tax, passport, visa and immigration, insurance, National Citizen Database, central excise, pensions and banking[21].

Under the State government mission mode list, which is to be finalized after consultations with States, the Action Plan envisages to take up land records, road transport, property registration, agriculture, treasuries, municipalities, gram panchayts, commercial taxes and police in union territories, initially for e-Governance activities.

Under the integrated services, e-commerce, e-business, common service centre and India portal have been identified as the Mission Mode projects.

Concerned Ministries such as; Finance, External Affairs, Home, Rural Development, Commerce and Industry, etc. and departments such as: Information Technology, Administrative Reforms, Public Grievances, etc., are among the organizations responsible for the Mission Mode project implementation.

The Action Plan would lay the foundation and provide the impetus for long growth of e-Governance and institutional mechanism, set up core infrastructure to create citizen centric and business-centric environments.

The major areas where ICT has been exploited successfully and is proving to be a boon to public at large are:

- The Indian railways have developed a computerized network wherein the reservation can be done for any place in India for any destination. This has further been made more public-friendly by providing the variety and departures, tourism information etc., through the Internet. The reservation through the Internet and mobiles phones has also been started thereby avoiding the hassles of going to the railway counters for booking the tickets.

- The banking system has also got streamlined with the setting up of ATM network. The public has the option of taking out money from their account anytime, anywhere. The various other services offered by banks are electronic fund transfer etc.

- The judicial system has been made operational wherein a person can find out the status of his legal case in Supreme Court and various High Courts. $\mathrm{He} / \mathrm{she}$ can get the complete orders date-wise, case number wise, judge wise, party-name wise, lawyerwise etc.

- The availability of CBSE results on the Internet is a major milestone in the education sector.

- Likewise, the availability of Income tax return form, tax deposit etc. is also available.

All the above initiatives provide a boon to the ordinary citizen directed to provide a responsive, user-friendly, transparent and faster system cutting the corruption, red-tapism and delay.

e-Initiatives involve much more than simple computerization of the various socio-administrative and personal activities of the citizens. e-Initiatives may assume to provide wider platforms to the willing people and they may also be expected to reach the hitherto unreached segments of society. Participatory decision making mechanism may be significantly made more effective through appropriate and relevant e-Initiatives. Citizen's grassroot level needs and social-welfare related aspirations may be adequately fulfilled through suitable intervention of eInitiatives. Education, health, transport, banking, justice, taxation and various other sectors may become the thrust areas where e-Initiatives may empower the ordinary citizens to solve their problems without any delay irrespective of the distance factor and complexity of the information network. Using the terminology that [22] the world has become flat and rules of game are same for all, effective, attainable and workable eInitiatives may pave the path in this respect.

\subsection{Uttarakhand state level e-Initiatives}

Uttarakhand has been created primarily to fulfill the demands and aspirations of the people of this predominantly hilly state, who felt that their problems in the specific context of the topography could not be addressed to the desired extent as a part of the combined Uttar Pradesh. Ever since the formation of the state, the Government has been consciously focusing on evolving a strategy towards meeting the mentioned objectives, towards this end, the key prongs of the strategy include:

- Rationalization of the role of the state bureaucracy to focus on critical areas

- Enhance the effectiveness, transparency and accountability in the processes of the state government

- Use of ICT tools for better delivery of development services to the people.

\subsubsection{Various e-Initiatives in Uttarakhand}

Computer education is an important ingredient in today's times for our school children. The State Government has entered into a MoU with Intel to provide Master Trainers in the schools in order to implement the vision of computer education to all students. All Government Intermediate Colleges as well as Secondary Schools have been equipped with computers [24]. Industries are being associated with ITI's \& Polytechnics and forging partnerships which are supposed to benefit all the Stakeholders. In the field of higher IT enabled course material and e-libraries have also been planned which would help overcome the shortage of teachers particularly in remote areas [25].

In respect of information technology the vision is to deploy IT as an effective tool for catalyzing economic growth and efficient governance resulting in the creation of a knowledgerich society with a high quality of life and to develop the State as an attractive destination for the IT industry. The key focus areas are:

- Development of IT infrastructure (connectivity backbone)

- Investing in HRD (Human Resource Development) in terms of IT skills. 
- Deploying e-Governance applications which are citizen focused and which aim at delivering Govt. services to the citizens at a place and time of his choice rather than the other way round.

- Promoting IT industry particularly the IT enabled service industry in the State.

\subsubsection{Telecommunication in Uttarakhand}

Uttarakhand has a well-developed communications network. The state is naturally endowed and has all prerequisites for developing as a preferred destination for IT \& ITes sector along with hardware production. Among the several initiatives undertaken to promote IT and ITes industry, Uttarakhand offers high speed connectivity with the establishment of an earth station at Dehradun and proposed earth stations at other locations. Facilities by BSNL and Reliance are also available. With an IT Park in Dehradun, an IT-BT park in Pantnagar, and several other upcoming projects, Uttarakhand is forgoing ahead as in IT-ITes state as an ideal IT-ITes destination.

\subsection{IT Vision and strategy}

- The state IT policy aims to encourage the use of IT in government not only as a tool for management and decision support systems, but also to re-engineer the processes to provide a more efficient, transparent, accountable and responsive (SMART) government to its citizens.

- Upgrade the quality of life of citizens by facilitating easy access to consumer applications of IT.

- Encourage private sector initiatives for the development of world class IT infrastructure adequate for the needs of citizens, industry and government.

- Upgrade and develop skills required for the IT industry and to accelerate its use in schools and colleges.

- The government's plan for the IT sector is threedimensional.

- Setting up infrastructure

- Building the capacity

- Developing software applications

\subsubsection{IT Infrastructure}

The government's initiative to introduce e-Governance is aimed at improving the efficiency of various departments. It is also expected to aid the government in interacting effectively with investors, other governments as well as the common public. Improving the transparency in the system also falls high on the government's agenda for reforms. Some of the projects include:

- The Uttarakhand State Wide Area Network (UKSWAN) project along with a Data Centre in place

- The state portal "Uttara" has been developed aming to provide information about all the 109 departments and institutions

- $\quad$ Common Service Centres (CSC)
- Development of Human Resources Management System

- $\quad$ Project Management Application for PWD

2.7.2 Key Uttarakhand e-Governance initiative:

- Development of Smart Card Infrastructure

- The world's first Microsoft IT Academy was established in Dehradun

- Uttarakhand is among the leading states in computer education

\section{8 e-Governance ranking}

A Study by leading IT publication 'Dataquest' and the top technology research firm International Data Corporation revealed that Uttarakhand was in 13th position in 2007-08 and in 12th position in 2008-09 with regard to e-Governance ranking [26].

\subsection{IT capacity building initiatives}

- The state has plans to achieve 100 per cent computer literacy for students and government employees. Some of the projects which have been under taken by the state are the following.

- Under project "Arohi” computer laboratories have been established in 1735 high schools and intermediate colleges.

- 23,953 teachers have been trained as master trainers with the help of Intel and Microsoft's project "Shiksha".

- A D-space library contains a digital repository of books, thesis, and papers from all universities in the state. These libraries have been established at the Birla Institute of Applied Sciences, Bhimtal, and the universities of Garhwal, Kumaon, and Pantnagar. The aim is to facilitate seamless sharing of resources amongst universities in Uttarakhand.

- Project Aarohi, one of the prestigious projects of Uttarakhand government, was adjudged as best IT initiative in education in India. This project is being implemented by Hiltron.

\subsection{IT and e- Initiatives in Uttarakhand}

In the state, maintaining pace with the global world, Government is drawing up a comprehensive program to ensure that the benefit of e-Governance reaches all sections of the society and economy.

Various IT activities, such as development of software applications packages, creation of e-Governance infrastructure, databases, digital/educational content, etc., in e-Governance 
domain, is part of Government's strategy in driving the IT penetration in Government offices.

NIC Uttarakhand State Unit, Dehradun has been instrumental in steering Information and Communication Technology applications in Government Departments at various levels, facilitating improvement in Government services, wider transparency in Government functions and resulting improvement in decentralized planning and management. The state unit was inaugurated on 10th November 2001 by the then Chief Minister of the state. Since its inception in year 2001, major activities undertaken by NIC in Uttarakhand can be categorized as follows:

- Sectoral ICT

- Web Applications

- Infrastructure \& Services

- Trainings

- Website (http://ua.nic.in)

IT has tremendous potential for developing a state like Uttarakhand. IT can be leveraged to move forward from the status of a developing to a developed state. It can help in bringing an administration, which is quick, responsive, transparent and accessible.

\section{RESEARCH METHODOLOGY}

In order to attain the objectives of the study, the following research methodology has been followed. Preliminary investigation about the e-Initiatives of the state has been checked and the perceptions of the experts towards the effectiveness of e-Initiatives in Uttarakhand have been analyzed and understood in the following manner:

\subsection{IAOEIU}

Questionnaire on the e-Initiatives, Impact assessment of eInitiatives in Uttarakhand has been prepared.

A scale named 'Impact Assessment of e-Initiatives in Uttarakhand' IAOEIU has been prepared for the study of eInitiatives. The questionnaire contains the feedback of different e-Initiatives of the state covering IT awareness, infrastructure issues, effectiveness, and necessity of the programme to the grass root levels. It is a five point scale and contains 28 statements. Out of these 28 statements 14 statements are positive and 14 are negative statements.

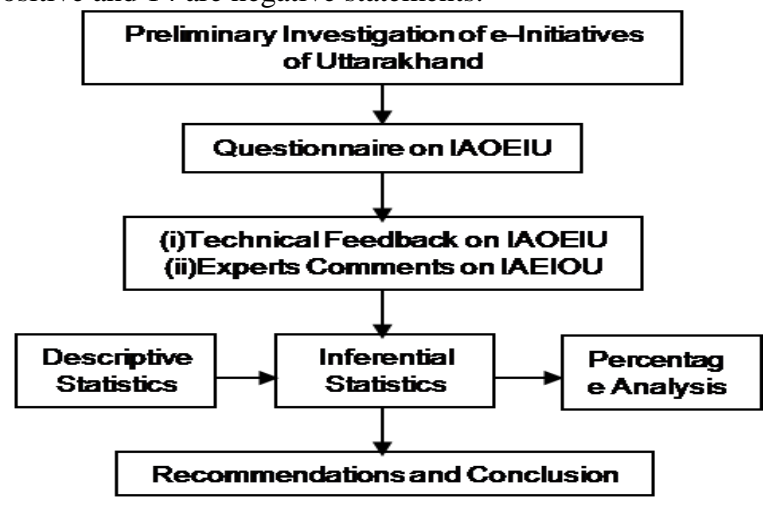

Figure 1 - Research Methodology
For a positive item the following scoring procedure has been employed:-

4 Marks awarded for strongly agree

3 Marks awarded for agree

2 Marks awarded for can't say

1 Mark awarded for disagree

0 Mark awarded for strongly disagree

For a negative item the scoring procedure is just reversed. The marking ystem is

0 Mark awarded for strongly agree

1 Mark awarded for agree

2 Mark awarded for can't say

3 Mark awarded for disagree

4 Mark awarded for strongly disagree

Scores on all the 28 items are added together and it fielded a score of the respondent in this scale. An individual score may be interpreted on the basis of IAOEIU "The higher the score the more favorable is the perception of the respondent towards the effectiveness of e-Initiatives and the lower the score the less favorable is the perception of the respondent towards the effectiveness of e-Initiatives". Fig 1 shows the sample questionnaire

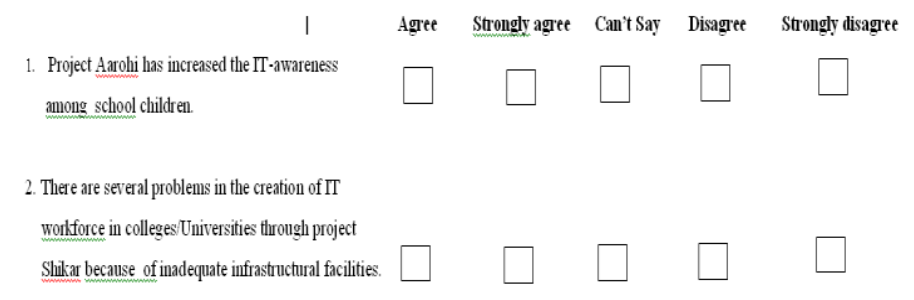

Figure 2: Sample questionnaire

\subsection{The IAOEIU of the Study}

The sample of the study consisted of 148 respondents. They were Computer experts, Computer teachers, Computer Education Related Students and computer users of government departments. Gender and educational qualification wise distribution of these 148 respondents has been mentioned in Table 1.

Table 1. Gender and educational qualification wise distribution of the respondents $(\mathrm{N}=148)$

\begin{tabular}{|l|c|c|c|c|c|}
\hline & $\begin{array}{l}\text { Under } \\
\text { Grad. }\end{array}$ & Grad. & $\begin{array}{l}\text { Post } \\
\text { Grad. }\end{array}$ & $\begin{array}{l}\text { Other } \\
\text { Qual. }\end{array}$ & Total \\
\hline Male & 02 & 17 & 69 & 24 & 112 \\
\hline Female & 02 & 03 & 25 & 06 & 36 \\
\hline Total & 04 & 20 & 94 & 30 & 148 \\
\hline
\end{tabular}

Grad. - Graduate

Gender and age-wise group distribution of these 148 respondents has been mentioned in Table 3 .

Table 2.Gender and age wise distribution of the respondents

\begin{tabular}{|l|l|l|l|ll|l|}
\hline & $\mathbf{N}=148)$ \\
& Yrs. & Yrs. & $\begin{array}{l}\text { 41-50 } \\
\text { Yrs. }\end{array}$ & $\begin{array}{l}>51 \quad \text { Yrs. } \\
\text { \& above }\end{array}$ & Total \\
\hline
\end{tabular}




\begin{tabular}{|l|c|c|c|c|c|}
\hline Male & 42 & 39 & 19 & 12 & 112 \\
\hline Female & 21 & 11 & 04 & 00 & 36 \\
\hline Total & 63 & 50 & 23 & 12 & 148 \\
\hline
\end{tabular}

As mentioned earlier, the sample included computer experts, computer teachers, computer education related students and others. The number of these sample respondents has been presented in table 4 .

Table 3.Gender and category/status wise distribution of the sample respondents $(\mathrm{N}=148)$

\begin{tabular}{|l|c|c|c|c|c|}
\hline & $\begin{array}{c}\text { Computer } \\
\text { experts }\end{array}$ & $\begin{array}{c}\text { Computer } \\
\text { Teacher }\end{array}$ & $\begin{array}{c}\text { Computer } \\
\text { related } \\
\text { Students }\end{array}$ & Others & Total \\
\hline Male & 44 & 24 & 01 & 43 & 112 \\
\hline Female & 04 & 12 & 05 & 15 & 36 \\
\hline Total & 48 & 36 & 06 & 58 & 148 \\
\hline
\end{tabular}

\subsection{Data Collection Procedure}

The relevant data were collected by employing the above mentioned tool IAOEIU. Information with regard to gender, age, educational qualification, status/category of the respondents ware also made known. Data were collected by personally contacting the respondents, through e-mail and through postal services.

Respondents were from Almora, Bageshwar, Pithoragarh, Udham Singh Nagar, Nainital, Chamoli, Haridwar, Deharadun, Champawat, Pouri,Tehari, Uttarkashi and Rudraprayag district of the state of Uttarakhand. District wise distribution of the sample respondents has been presented in Appendix 2. The data were collected in the month of October, November and December, 2009.

In addition to the above, written comments of 25 experts were also obtained with regard to the e-Initiatives in Uttarakhand and these have also been elaborated in chapter IV.

\subsection{Data Analysis}

In order to attain the objectives 3 of the study, the following statistics were employed:

- Descriptive Statistics

- Inferential Statistics

A master chart (MC) has been prepared which contains the following information with regard to the sample respondents:

$\begin{array}{lll}\text { (1) Gender } & \text { - } & \\ \text { Male } & - & 1 \\ \text { Female } & - & 2\end{array}$

\section{Code}

(2) Age - less than

Less than 30 years

$30-40$ years

41-50 years

2

51 years \& above

(3) Educational Qualification

Under graduates

Graduates

Post-graduates

Other Qualification

(4) Category/Status

Computer experts
Computer Teachers 2

Computer Education Related Students 3
Others

\subsection{Descriptive Statistics}

In order to understand the nature of the distribution of the scores of the IAOEIU (scale) of the 148 sample respondents, the values of the relevant Descriptive statistics were prepared made known and these have been presented in table 5 .

Table 4 Values of the various descriptive Statistics with regard to the IAOEIU scores of the sample respondents $(\mathrm{N}=148)$

\begin{tabular}{|c|l|c|c|}
\hline S. & \multicolumn{1}{|c|}{ Statistics } & Symbol & Value \\
\hline 1 & Mean & $\mathrm{M}$ & 56.43 \\
\hline 2 & Mode & $\mathrm{Mo}$ & 54.00 \\
\hline 3 & Median & $\mathrm{Mdn}$ & 54.83 \\
\hline 4 & Standard Deviation & $\mathrm{SD}$ & 8.346 \\
\hline 5 & Standard Error of Mean & $\mathrm{SE}_{\mathrm{m}}$ & 0.686 \\
\hline 6 & Standard Error of Median & $\mathrm{SE}_{\mathrm{md}}$ & 0.859 \\
\hline 7 & $\begin{array}{l}\text { Standard Error of Standard } \\
\text { Deviation }\end{array}$ & $\mathrm{SEsd}$ & 0.487 \\
\hline 8 & Tenth percentile & $\mathrm{P}_{10}$ & 47.82 \\
\hline 9 & Twenty Fifth Percentile & $\mathrm{P}_{25}$ & 50.82 \\
\hline 10 & Seventy Fifth Percentile & $\mathrm{P}_{75}$ & 58.56 \\
\hline 11 & Ninetieth Percentile & $\mathrm{P}_{90}$ & 65.75 \\
\hline 12 & Skewness & $\mathrm{S}_{\mathrm{k}}$ & +0.575 \\
\hline 13 & Kurtosis & $\mathrm{K}_{\mathrm{u}}$ & 0.247 \\
\hline
\end{tabular}

Entries in Table 4 reveal the following:

- The values of Mean, Mode and Median are 56.43, 54.00 and 54.83 respectively. The lowest score is 42 and the highest score is 86 . This shows that there is not a very large deviation in the values of these three central tendencies.

- The values of the Standard Errors of Mean, Median and Standard Deviation are $0.686,0.859$ and 0.487 respectively. There values are not very large and hence the values of the Mean, Mode and Median may be accepted as approximations of the values of the respective parameters.

- The distribution is slightly positively skewed as the value of Skewers is +0.575 in nature.

- The value of Kurtosis is 0.247. It means that the distribution is slightly leptokurtic in nature.

On the basis of the above narration the nature of the distribution of IAOEIU scale scores may be assumed to tend towards the shape of a Normal Probability Curve (NPC). Hence it has been decided to compute the values of $\mathrm{t}$ - ratios for ascertaining the significance of difference in the mean IAOEIU scale scores of the various relevant groups of the sample respondents.

\subsection{Inferential Statistics}

Values of t-ratios were computed to ascertain the significance of differences in the mean IAOEIU scale scores of the following groups of the respondents respectively: 
- Educational qualification wise groups

- Gender wise groups

- $\quad$ Age wise groups

In addition to the above, appropriate procedure was followed to find out the number and percentages of the respondents to attain the following sub-objectives:

(1) To find out the number of respondents who either "agreed or strongly agreed" with regard to the 28 statements respectively of IAOEIU Scale.

(2) To find out the number of respondents who respondents in 'Can't Say' with regard to the 28 statements of IAOEIU scale respectively.

(3) To find out the number of respondents who either "disagreed or strongly disagreed" with regard to the 28 statements of IAOEIU scale respectively.

(4) To make a list of six statements of IAOEIU scale towards which "first six highest percentage of respondents" responded in "either agree or strongly agree"

(5) To make a list of six statements of IAOEIU scale towards which "last six lowest percentages of respondents" responded in "either agree or strongly agree."

(6) To make a list of five statements of IAOEIU scale towards which "first five highest percentage of respondents" responded in "Can't say"

(7) To make a list of five statement of IAOEIU scale towards which "last five lowest percentages of respondents" responded in "Can't Say"

(8) To make a list of five statements of IAOEIU scale towards which "first five highest percentages of respondents" responded in "either disagree or strongly disagree"

(9) To make a list of "last five lowest percentages of respondents in "either disagree or strongly disagree"

Furthermore, percentage analysis has been done to attain the following sub-objectives:

(1) To identify the statement towards which highest number of respondents "strongly agreed."

(2) To identify the statements towards which "lowest number of respondents "strongly agreed"

(3) To identify the statements towards which highest number of respondents "agreed."

(4) To identify the statements towards which lowest number of respondents "agreed."

(5) To identity the statements towards which highest number of respondents "Can't Say."

(6) To identify the statements towards which lowest number of respondents "Can't Say".

(7) To identify the statements towards which highest number of respondents "Strongly disagreed".

(8) TO identify the statements towards which lowest number of respondents "Strongly disagreed".

(9) To identify the statements towards which highest number of respondents" disagreed".
(10) To identify the statements towards which lowest number of respondents "disagreed".

The rejection /acceptance of a hypothesis is decided and determined on the basis of the significance/insignificance of the relevant statistics of 0.05 level of significance. The data is statistically analyzed using Statistical Package for Social Sciences (SPSS)

\section{DATA ANALYSIS}

This chapter deals with the statistical analysis of the data collected to attain the following two objectives of the study:

(1) To analyze and understand the perceptions of experts towards the effectiveness of e-Initiatives in Uttarakhand.

(2) To collect and elaborate the comments of the experts on eInitiatives in the mean Uttarakhand.

\subsection{Qualification wise four groups of the respondents:}

t-ratio of the respondents is shown in table 5 .

Entries in Table 6 reveal that educational qualification wise four groups of the respondents do not differ in their perception towards the effectiveness of e-Initiatives. The perception appearances of the respondents are shown in Figure 6

Table 5. Comparison of the Perception towards the effectiveness of e-Initiatives of qualification wise four groups of the respondents.

\begin{tabular}{|c|c|c|c|c|c|}
\hline $\begin{array}{l}\text { S. } \\
\text { No. }\end{array}$ & $\begin{array}{l}\text { Qualification } \\
\text { wise Group }\end{array}$ & $\mathrm{N}$ & $\mathrm{M}$ & SD & t-ratio, df \\
\hline 1. & $\begin{array}{l}\text { Under } \\
\text { Graduates }\end{array}$ & 04 & 53.00 & 4.54 & \multirow{4}{*}{$\begin{array}{l}\mathrm{t} 1,2=1.51,22 \\
\mathrm{t} 1,3=1.46,96 \\
\mathrm{t} 1,4=0.78,32 \\
\mathrm{t} 2,3=0.44,112 \\
\mathrm{t} 2,4=0.91,48 \\
\mathrm{t} 3,4=0.75,122\end{array}$} \\
\hline 2. & Graduc & 20 & 57.4 & 8.15 & \\
\hline 3. & Post Graduates & 94 & 56.53 & 7.89 & \\
\hline 4. & $\begin{array}{l}\text { Other } \\
\text { Qualification }\end{array}$ & 30 & 55.17 & 8.93 & \\
\hline
\end{tabular}

Note: - All the values of the t-ratio are insignificant at 0.05 Level of significance.

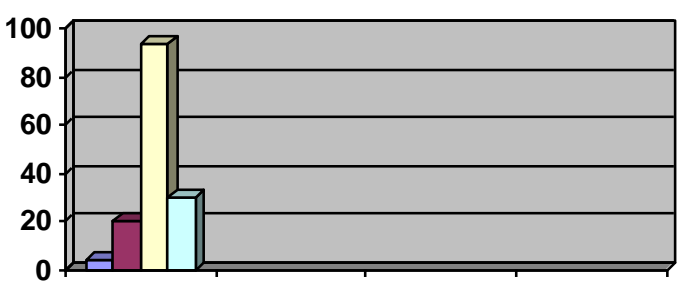

\begin{tabular}{|ll|}
\hline$\square$ Under Graduates & $\square$ Graduates \\
$\square$ Post Graduates & $\square$ Other Qualification
\end{tabular}

Figure 3 - Qualification wise Group

\subsection{Gender wise two groups of the respondent scores}

Table 6. the comparison of the Perception towards the effectiveness of e-Initiatives of Gender wise two groups of the respondents

\begin{tabular}{|c|l|c|c|c|c|}
\hline S. No. & Gender & $\mathbf{N}$ & $\mathbf{M}$ & SD & t-ratio, df \\
\hline 1. & Male & 112 & 56.10 & 8.28 & $\mathrm{t}=0.5,144$ \\
\hline
\end{tabular}




\begin{tabular}{|c|l|l|l|l|l|}
\hline 2. & Female & 36 & 56.83 & 7.40 & \\
\hline Note:-The value of t-ratio is insignificant at 0.05 Level of \\
significance
\end{tabular}

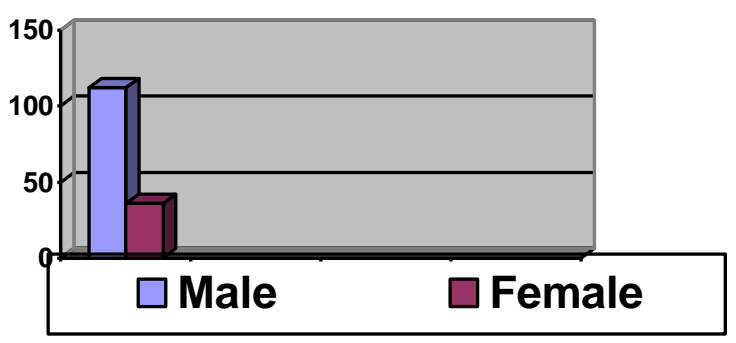

Figure 4 - Gender wise Group

Entries in Table 7 reveal that gender wise two groups of the respondents do not differ in their perception towards the effectiveness of e-Initiatives. Fig 3 shows the gender wise distribution.

\subsection{Age wise four groups of the respondents scores}

The comparison of the Perception towards the effectiveness of e- Initiatives of age-wise four groups of the Respondents.

Table 7. shown the age wise distribution of the feedback analysis.

\begin{tabular}{|c|c|c|c|c|c|}
\hline S.No. & $\begin{array}{l}\text { Age-Wise } \\
\text { Group Yrs }\end{array}$ & $\mathbf{N}$ & M & SD & t-ratio,df \\
\hline 1. & $<30$ & 63 & 56.71 & 7.09 & \multirow{4}{*}{$\begin{array}{l}\mathbf{t}_{1,2}=0.21,111 \\
\mathbf{t}_{1,3}=0.23,84 \\
\mathbf{t}_{1,4}=1.77,73 \\
t_{2,3}=0.10,71 \\
t_{2,4}=1.59,60 \\
t_{3,}=0.87,33\end{array}$} \\
\hline 2. & $30-40$ & 50 & 56.40 & 8.20 & \\
\hline 3. & $41-50$ & 23 & 56.13 & 11.23 & \\
\hline 4. & $>51$ & 12 & 53.75 & 4.88 & \\
\hline
\end{tabular}

Note: - All the values of the six t-ratios are insignificant at 0.05 level of significance.

Entries in Table 8 reveal that age-wise four groups of the respondents do not differ in their perception towards the effectiveness of e-Initiatives. Fig 4 age-wise distributions.

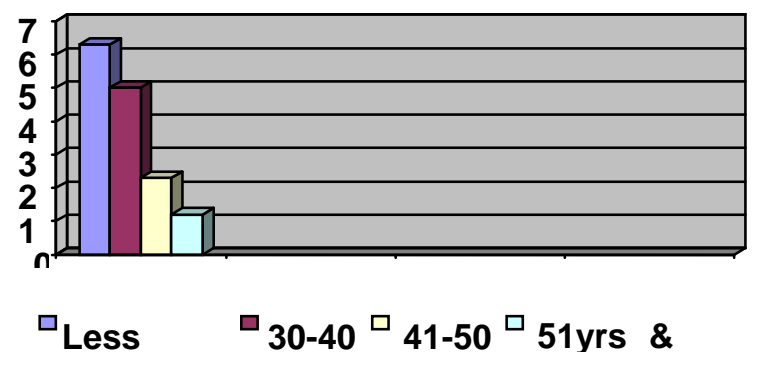

Figure 5 - Age wise group

\subsection{Expert Opinion Analysis (SWOT)}

"GOOD GOVERNANCE" improves the process of decisionmaking and the process by which decisions are implemented. Governance can be used in several contexts such as corporate governance, international governance, national governance and local governance. It encompasses the entire process of public administration, the process underlying the formulation of public policies, the Human Resource Development efforts required for re-skilling the government machinery, prioritization, and efficient management of public resources and above all redesigning the various instruments used to realize the concept of a welfare state. Table 8 to 11 shows the expert analysis of the survey.

Table 8 Social Aspects

\begin{tabular}{|c|c|}
\hline Strengths & Weaknesses \\
\hline $\begin{array}{l}\text { - People eager to learn } \\
\text { Internet } \\
\text { - People eager to learn IT } \\
\text { skills }\end{array}$ & $\begin{array}{l}\text { - Basic education poor } \\
\text { - Low literacy } \\
\text { - Low IT literacy } \\
\text { - Different Languages } \\
\text { - Public acceptance of self } \\
\text { service models }\end{array}$ \\
\hline Opport & \\
\hline $\begin{array}{l}\text { - Employment increases } \\
\text { - Education system will } \\
\text { improve } \\
\text { - People get structural job } \\
\text { - Cheap manpower will } \\
\text { widely available } \\
\text { - Promotion of internet }\end{array}$ & $\begin{array}{l}\text { - Brain drain of IT skilled } \\
\text { people after training } \\
\text { - Influence of other culture } \\
\text { - Resistance of people } \\
\text { - Digital divide } \\
\text { - Privacy }\end{array}$ \\
\hline
\end{tabular}

Table 9 Political Aspects

\begin{tabular}{|c|c|}
\hline Stre & We: \\
\hline $\begin{array}{l}\text { - } \text { Combination with } \\
\text { democratization Political } \\
\text { reforms } \\
\text { - Internet will work as pull } \\
\text { factor } \\
\text { - Modern image }\end{array}$ & $\begin{array}{l}\text { - Lack of Budget } \\
\text { - Lack of cyber laws } \\
\text { - Slow decision making } \\
\text { process } \\
\text { - Hierarchical structures } \\
\text { - Short term approach } \\
\text { Integration and reform } \\
\end{array}$ \\
\hline & \\
\hline $\begin{array}{l}\text { - Raise external funding } \\
\text { - Show competitive edge } \\
\text { - Transparency causes } \\
\text { - Natural change } \\
\text { processes } \\
\text { - Reinvent government }\end{array}$ & $\begin{array}{l}\text { Bureaucracy } \\
\text { - Piracy, misuse } \\
\text { - Corruption } \\
\text { - Maintaining disorder, no } \\
\text { transparency } \\
\text { - Political instability } \\
\text { - Resistance } \\
\end{array}$ \\
\hline
\end{tabular}

\begin{tabular}{|l|l|}
\hline \multicolumn{2}{|c|}{ Table 10 Economic Aspects } \\
\hline \multicolumn{1}{|c|}{ Strengths } & \multicolumn{1}{|c|}{ Weaknesses } \\
\hline $\begin{array}{l}\text { - e-Governance argument for } \\
\text { external funding } \\
\text { - Transparency for businesses } \\
\text { (procurement) }\end{array}$ & $\begin{array}{l}\text { • Lack of Investors } \\
\text { • Budget control }\end{array}$ \\
\hline \multicolumn{1}{|c|}{ Opportunities } & Threats \\
\hline $\begin{array}{l}\text { - Higher cost efficiency } \\
\text { - New business }\end{array}$ & Corruption \\
\hline
\end{tabular}

4.11 Technological Aspects

\begin{tabular}{|c|c|}
\hline Strengths & Weaknesses \\
\hline $\begin{array}{l}\text { - Everything is new: no } \\
\text { negative legacy } \\
\text { - Leapfrogging possible } \\
\text { - Good Telecom and Mobile } \\
\text { users Internet as pull factor } \\
\text { - Use of Open source } \\
\text { software }\end{array}$ & $\begin{array}{l}\text { - Shortage IT skills } \\
\text { - High cost of internet } \\
\text { - Heterogeneous data } \\
\text { - Lack of IT standards } \\
\text { - Software licenses }\end{array}$ \\
\hline Opportunities & Threats \\
\hline $\begin{array}{l}\text { - 2nd hand hardware } \\
\text { available } \\
\text { - Use of PPP mode for } \\
\text { technology outsourcing }\end{array}$ & - Dependency of technology \\
\hline
\end{tabular}




\section{CONCLUSION}

Peoples are eager to learn IT but because of lower IT literacy they are unable to learn IT. If they are able to learn ITES it will increase the possibility of employability. As matter fact there ample possibility of imparting ITES for the betterment of public.

\section{REFERENCES}

[1] Sharma, MK, 2009, A strategy for e-Initiatives for Uttarakhand, Ph.D thesis, Kumaun University, India.

[2] NCAER; Draft Uttarkhand Development Report, 2009.

[3] NCAER; Draft Uttarkhand Development Report, 2009.

[4] Egov, 2010, Magazine on E-Governance.

[5] http://www.presidencia.gov.co/webpresi/buscar.htm last accessed on 30 March 2010

[6] http://www.taninet.com. Last accessed on 30 March 2010

[7] http://www.parliament.gov.na last accessed on 30 March 2010

[8] http://www1.worldbank.org/publicsector/egov/eprocureme nt_chile.htm last accessed on 30 March 2

[9] http://010www.wam.umd.edu/ abbate/Estonia/EestiNet/to pics/ tiger.html last accessed on 30 March 2010

[10] www.cmc.gov.za/council/ last accessed on 30 March 2010

[11] http://www.aceproject.org/main/english/et/ety02.htm last accessed on 30 March 2010

[12] http://www.pms.ba.gov.br/indexE1024.html last accessed on 30 March 2010

[13] Holliday, I. 2002. "Building e-government in East and Southeast Asia: Regional rhetoric and national (in) action”. Public Administration and Development, Vol.22 .

[14] Norris, P. (2000). "Internet World: Parties, Government and Online Democracy", a paper presented at IPSA World Congress 2000.5.
[15] Goulet, Denis, 2006. "Development Ethics at Work: Exploration1960-2002”Routledge.

[16] Ghere, Richard K. and Young, Brian A. (1998) 'The Cyber-management Environment: Where Technology and Ingenuity Meet Public Purpose and Accountability', Public Administration and Management: An Interactive Journal 3(1).[http://www.pamij.com/gypaper.html]

[17] Chandrasekhar, R, 2004"National E-Governance Action Plan"

[18] Sameer, Sachdeva, 2003 "White Paper on E-Governance Strategy in India", World Bank, Washington.

[19] Teicher, J., O. Hughes \& N. Dow. 2002. E-government: a new route to public sectorquality, Managing Service Quality, Vol. 12(6).

[20] Saini, AK, 2003"e-Governance: A Road to Good Governance," Annual Convention of the Computer Society of India.

[21] Chandrasekhar, R, 2004 "National E-Governance Action Plan"

[22] Suresh Balakrishann, 2001 "Information Technology in Public Administration: Andhra Pradesh", Public Affairs Center, Bangalore.

[23] Source: Ministry of Science \& Technology, Government of India, 2009-10.

[24] NCAER; Draft Uttarkhand Development Report, 2009

[25] Uttara Portal Accessed on December 2009,

[26] Dataquest, Indian Government State Rediness Report 2008-09.

[27] Sharma, MK, 2009, A strategy for e-Initiatives for Uttarakhand, Ph.D thesis, Kumaun University, India

[28] Sharma, MK, 2009, A strategy for e-Initiatives for Uttarakhand, Ph.D thesis, Kumaun University, India. 